Journal of Environmental and Agricultural Studies

ISSN: $2710-140$

DOI: $10.32996 /$ jeas

Journal Homepage: www.al-kindipublisher.com/index.php/jeas

\title{
Analysis of Lettuce (Lactuva Sativa L) Farming Efficiency, Jaranguda Village, Merdeka District, Karo Regency
}

\author{
Asmina Herawaty Sinaga ${ }^{1} \square$ Rosmalina Sinaga ${ }^{2}$ and Rosmaria Girsang ${ }^{3}$ \\ ${ }^{1}$ Universitas Darma Agung Medan, Indonesia \\ ${ }^{2}$ Universitas Sisingamangaraja XII Tapanuli, Indonesia \\ ${ }^{3}$ Universitas Pembangunan Panca Budi Medan, Indonesia
}

$\square$ Corresponding Author: Asmina Herawaty Sinaga, E-mail: asminasinagauda@gmail.com

ARTICLE INFORMATION ABSTRACT

Received: 11 October 2021

Accepted: 14 November 2021

Published: 22 December 2021

DOI: 10.32996/jeas.2021.2.2.11

\section{KEYWORDS}

Lettuce, technical efficiency, price efficiency, economic efficiency, production factors, production, income.
The research aims to know the effect of factors of production on the production of lettuce farming, to determine the level of technical, allocative, and economic efficiency of the use of production factors of lettuce farming and to determine the level of profit that can result from lettuce farming. The reason for choosing the area was because the majority of the population were cultivating lettuce plants. The results showed that: the influence of production inputs (seeds, fertilizers, pesticides, labour and land area) significantly influence the production of lettuce farming. The level of efficiency in the use of production factors (seeds, fertilizers, pesticides, labour and equipment) has not been technical, price, and economically efficient. Net income per farmer amounted to Rp. 2,608,062.,63, per month amounted to Rp. 869,354. 21 when compared to the UMK of Rp. 2,829,558, the income of lettuce farming in the study area was relatively low.

\section{Introduction}

A farmer is technically said to be more efficient (technical efficiency) compared to another if the farmer can physically produce higher production using the same factors of production. In contrast, a farmer can achieve price efficiency if he can maximize profits (capable of equating the marginal value of the product of each variable production factor with its price). Economic efficiency occurs when price efficiency and technical efficiency occur. The difference in efficiency between a group of farms can be caused by differences in technical efficiency, price efficiency, or both.

a. Technical Efficiency

Technical efficiency can be calculated by finding the derivative of each input using a formula. After knowing the entire formula from all samples, the data is processed using the Lindo program. After knowing the variables, the efficiency level can be calculated. It can be said that technical efficiency is if the level of farming efficiency is more than one hundred percent.

b. Price Efficiency

According to Susantum (2010), price efficiency is achieved when the ratio between the marginal productivity value of each input (NPMxi) and the input price (vi) or $\mathrm{ki}=1$. This condition requires NPMx to be equal to the price of production factor $\mathrm{X}$ or can be written as follows:

$$
\frac{b Y P y}{X}=\mathrm{Px}
$$

Copyright: (c) 2021 the Author(s). This article is an open access article distributed under the terms and conditions of the Creative Commons Attribution (CC-BY) 4.0 license (https://creativecommons.org/licenses/by/4.0/). Published by Al-Kindi Centre for Research and Development, London, United Kingdom. 


$$
\frac{b Y P y}{X}=1
$$

Where:

Px: factor price of production $\mathrm{x}$

According to Soekartawi (2011), NPMx is not always the same as Px in many cases. What often happens is:

1. $($ NPMx $/ P x)>1$; This means that the use of input $X$ is not yet efficient; to achieve efficiency, input $X$ needs to be added.

2. $(N P M x / P x)<1$; means that the use of input $X$ is not efficient; to achieve efficient input, $X$ needs to be reduced.

c. Economic Efficiency

Economic efficiency is a product of technical efficiency and price efficiency (Susantum, 2010). So economic efficiency can be achieved if the efficiency of both has been achieved so that it can be written in the following formula:

$$
\mathrm{EE}=\mathrm{ET} . \mathrm{EH}
$$

Where:

$$
\begin{aligned}
& \text { EE: Economic Efficiency } \\
& \text { ET: Technical Efficiency } \\
& \text { EH: Price Efficiency }
\end{aligned}
$$

\section{Data analysis method}

To answer hypothesis (1), namely to see the level of technical efficiency, price efficiency, and economic efficiency, the following formula is used:

\subsection{Technical Efficiency}

To see the level of technical efficiency of the use of production factors in lettuce farming in Selrauda Village, Merdeka District, Karo Regency, a technical efficiency level measurement is used, which can be seen from the results of data processing with the help of Frontier Version 4.1c software. The justification for the value of technical efficiency is as follows: If the value of technical efficiency is equal to one, then the use of inputs or production factors is efficient. If the value of technical efficiency is less than one (not equal to one), then the use of inputs or production factors is not efficient (Mubyarto, 2008). To get the technical efficiency (TE) of lettuce farming can be done with the following calculations:

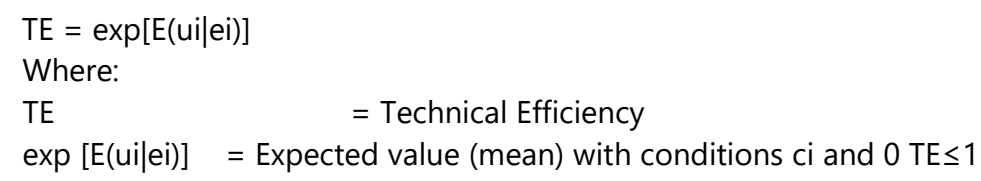

If the TE value is closer to 1 , then lettuce farming can be said to be more technically efficient, and if the TE value is getting closer to 0 , then farming can be said to be more technically inefficient (Mubyarto, 2008).

\subsection{Price Efficiency}

According to Nicholson (2015), price efficiency is achieved if the ratio between the marginal productivity value of each input (NPMxi) and the input price (vi) is equal to 1. This condition requires NPMx to be equal to the price of production factor X. According to Soekartawi (2013), inefficiency, the price is reached when the ratio between the marginal productivity value of each input (NPMxi) and the input price (vi) is equal to 1.

$$
\begin{aligned}
& \mathrm{NPM}=\mathrm{Px} \\
& \frac{\text { b.Y.P } P_{x}}{X}=1
\end{aligned}
$$

Where:

$\mathrm{b} \quad=$ Production elasticity

$\mathrm{Y}=$ Production

$\mathrm{Py}=$ production price

$\mathrm{X}=$ Number of factors of production $\mathrm{Y}$

$\mathrm{px} \quad=$ Price of factors of production $\mathrm{X}$ 
In this case, the values of $Y, P y, X$, and $P$ are taken from the average, so the above equation can be written as follows:

$$
\frac{b . Y . P_{x}}{X . P_{y}}=1
$$

In actual fact, the value equation is not equal to 1 ; what often happens is (NPM / Px) $>1$, which means that the use of factor $X$ is not efficient. In order to achieve efficiency, the use of production factor $X$ needs to be increased $(N P M / P x)<1$. This means that the use of production factor $X$ is not efficient. To be efficient, the use of input $X$ needs to be reduced.

\subsection{Economic Efficiency}

Nicholson (2015) states that economic efficiency is the product of all technical efficiency with the price efficiency of all input factors, a technically efficient allocation of resources where the combination of output produced also reflects people's preferences. In other words, economic efficiency will be achieved if technical efficiency and price efficiency are achieved.

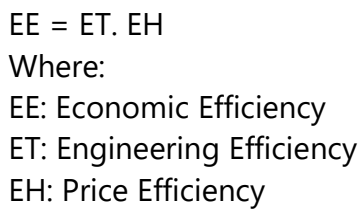

The test criteria are seen from the value of economic efficiency which is equal to one, then the farming carried out has reached the level of efficiency. To answer the hypothesis (2), it was analyzed using the OLS (Ordinary Least Square) method using a multiple linear regression estimator model, mathematically it can be written as follows:

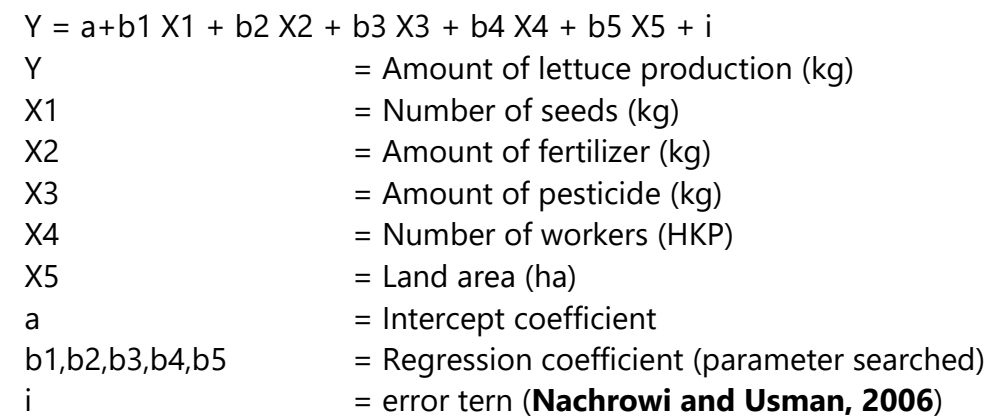

To find out whether seeds (X1), fertilizers (X2), pesticides (X3), labour (X4) and land area (X5) simultaneously have a significant effect or not on lettuce production $(\mathrm{Y})$, the $\mathrm{F}$ test is used. The hypothesis used is:

H0: There is no effect of seed, fertilizer, Pesticide, and labor variables Work on lettuce production $(\mathrm{Y})$.

$\mathrm{H1}$ : There is a variable influence of seeds, fertilizers, pesticides, and labor Work on lettuce production $(\mathrm{Y})$.

If: Fcount Ftable then accept H0, reject H1 Fcount Ftable then accept $\mathrm{H} 1$, reject $\mathrm{HO}$

To find out whether the variables of seeds, fertilizers, pesticides, labor and the land area had a significant partial effect on lettuce production $(\mathrm{Y})$, the t-test was used.

The hypotheses used are:

$\mathrm{HO}=0$ : There is no effect of variable $\mathrm{Xi}$ on lettuce production $(\mathrm{Y})$ $\mathrm{H} 1 \mathrm{0}$ : There is an effect of variable $\mathrm{Xi}$ on lettuce production $(\mathrm{Y})$ If : tcount > ttable or -tcount < -ttable then accept $\mathrm{H} 1$, reject $\mathrm{H} 0$ tcount < ttable or -tcount > -ttable then accept $\mathrm{H} 0$, reject $\mathrm{H} 1$

(Suharyadi and Purwanto, 2011) 


\section{Research Results and Discussion}

\subsection{Technical Efficiency}

To find the technical efficiency of lettuce farming, the formula $\frac{N P M_{x}}{P x}$ with the calculation looks like in the following table:

Table 1. The Level of Technical Efficiency of Lettuce Farming in the Research Area, 2019

\begin{tabular}{|l|r|r|r|r|r|r|r|r|l|}
\hline No & $\mathrm{H} 1$ & $\mathrm{X}$ & $\mathrm{Y}$ & $\mathrm{PPMx}$ & \multicolumn{1}{|c|}{$\mathrm{px}$} & $\mathrm{Py}$ & $\mathrm{NPM}$ & $\frac{N M_{x}}{P x}$ & Criteria \\
\hline 1 & 0.017 & 173.38 & 544.42 & 0.05 & 1,500 & 14,000 & 700 & 0.47 & Not efficient \\
\hline 2 & 0.033 & $1,754,129$ & 544.42 & 0.01 & 2.217 & 14,000 & 140 & 0.06 & Not efficient \\
\hline 3 & 0.631 & 384.81 & 544.42 & 0.89 & 110 & 14,000 & 12,460 & 113.27 & Not Efficient \\
\hline 4 & 3,749 & 12.84 & 544.42 & 11.31 & 100,000 & 14,000 & 158,340 & 1.58 & Not Efficient \\
\hline 5 & 1,000 & 8.31 & 544.42 & 65.51 & 89,900 & 14,000 & 917,140 & 10.21 & Not Efficient \\
\hline
\end{tabular}

From the table, it can be seen that the production factor of seeds and fertilizers has a value of NPMx / Px $<1$, so it is still technically inefficient, so it needs to be reduced to be technically efficient, while the production factors of pesticides, labor and equipment have a value of NPMx / Px > 1 so that technically these three factors must be added in order to be technically efficient in increasing lettuce production. According to Soekartawi (2003), if NPMx / Px $>1$, the use of production factor X is not yet technically efficient. To achieve efficiency, input X must be added. If NPMx / Px = 1, it means that the use of factor $X$ is efficient. If NPMx / Px < 1, it means that the use of production factor $X$ is not efficient; to achieve efficiency, input $X$ needs to be reduced.

\subsection{Price Efficiency}

To find price efficiency, use the formula $\frac{b \cdot Y \cdot P x}{X . P x}$ with calculations as shown in the following table:

Table 2 Level of efficiency of Lettuce Farming Prices in the Research Area, 2019

\begin{tabular}{|l|r|r|r|r|r|r|r|l|}
\hline No & $\mathrm{H} 1$ & \multicolumn{1}{|c|}{$\mathrm{X}$} & $\mathrm{Y}$ & \multicolumn{1}{c|}{$\mathrm{px}$} & \multicolumn{1}{c|}{$\mathrm{Py}$} & $\mathrm{NPM}$ & $\frac{\text { b.Y.Px }}{X . P x}$ & \multirow{2}{*}{ Criteria } \\
\hline 1 & 0.017 & 173.38 & 544.42 & 1,500 & 14,000 & 700 & 0.47 & Not efficient \\
\hline 2 & 0.033 & $1,754,129$ & 544.42 & 2.217 & 14,000 & 140 & 0.06 & Not efficient \\
\hline 3 & 0.631 & 384.81 & 544.42 & 110 & 14,000 & 12,460 & 113.62 & Not Efficient \\
\hline 4 & 3,749 & 12.84 & 544.42 & 100,000 & 14,000 & 158,340 & 22.25 & Not Efficient \\
\hline 5 & 1,000 & 8.31 & 544.42 & 89,900 & 14,000 & 917,140 & 10.21 & Not Efficient \\
\hline
\end{tabular}

Source: Data processed (2020)

From the table, it can be seen that the production factor of seeds and fertilizers has a value of bYPy / X.Px $<1$, so it is not efficient, where the use of both factors must be reduced in order to increase lettuce production in the study area efficiently. While the pesticide production factors, labor and land area have bYPy / X.Px $>1$, so it is not efficient, where the use of these three factors must be added to be efficient. According to Soekartawi (2003), if bYPy / X.Px > 1, the use of production factor X is not efficient. To achieve efficiency, the input X must be added. If bYPy / X.Px =1, it means that the use of factor $X$ is inefficient. From the results of the calculation of the value of price efficiency, it can be explained that the average use of allocative factors of production is not efficient,

3.3 Economic Efficiency

To find economic efficiency, the formula $\mathrm{EE}=\mathrm{Et} \times \mathrm{EH}$ is used as shown in the following table: 
Table 3. Economic Efficiency of Use of Production Factors in Lettuce Farming in Indonesia Research Area, The Year 2019

\begin{tabular}{|l|l|r|r|r|l|}
\hline No & \multicolumn{1}{|c|}{ Input } & $\begin{array}{r}\text { Technical } \\
\text { Efficiency }\end{array}$ & \multicolumn{1}{c|}{$\begin{array}{c}\text { Price } \\
\text { Efficiency }\end{array}$} & $\begin{array}{l}\text { Economic } \\
\text { Efficiency }\end{array}$ & Criteria \\
\hline 1 & Seeds & 0.47 & 0.49 & 0.23 & Not efficient \\
\hline 2 & Fertilizer & 0.06 & 0.06 & 0.00 & Not efficient \\
\hline 3 & Pesticide & 113.27 & 113.62 & 12.869 & Not Efficient \\
\hline 4 & Labor & 1.58 & 22.25 & 35.15 & Not Efficient \\
\hline 5 & Equipment & 10.21 & 10.21 & 104.24 & Not Efficient \\
\hline
\end{tabular}

Sumber: Data processed (2020)

From the table, it can be concluded that the provision of production factors in lettuce farming in the research area is not yet economically efficient, because the value of economic efficiency is greater than one (EE > 1). According to Soekartawi (2003), efficiency is defined as an effort to use the smallest input to get the maximum production. Such a situation will occur if the farmer is able to make an effort to make the marginal product value (NPMx) for an input equal to the input price (Px). According to Semaoen (2012), the traditional test of allocative efficiency is based on the assumption that producers use the same level of technology, product and input prices.

1. Effect of Production Inputs (Seeds, Fertilizers, Pesticides, Labor and Land Area) on Lettuce Farming Production in the Research Area

a. Cobb-Douglas test

To determine the effect of production inputs (seeds, fertilizers, pesticides, labor, and land area), the Cobb-Douglas test was carried out using the SPSS-24 program. The results of the Cobb-Douglas test can be seen in the following table:

Table 4. Cobb-Douglass Test Factors of Seeds, Fertilizers, Pesticides, Labor and Land Area Against Lettuce Production in the Research Area

\begin{tabular}{|c|c|c|c|c|c|c|}
\hline \multicolumn{7}{|c|}{ Coefficients } \\
\hline & & \multicolumn{2}{|c|}{$\begin{array}{l}\text { Unstandardized } \\
\text { Coefficients }\end{array}$} & \multirow{2}{*}{$\begin{array}{c}\text { Standardized } \\
\text { Coefficients } \\
\text { Beta }\end{array}$} & \multirow[b]{2}{*}{$\mathrm{t}$} & \multirow[b]{2}{*}{ Sig. } \\
\hline \multicolumn{2}{|c|}{ Model } & $B$ & Std.Error & & & \\
\hline \multirow[t]{6}{*}{1} & (Constant) & 34,080 & 97,918 & &, 348 &, 731 \\
\hline & Seeds & 0.017 & ,352 &, 033 & 0.047 &, 963 \\
\hline & Fertilizer &, 033 & .044 & 0.60 & ,742 & 465 \\
\hline & Pesticide & ,631 & ,089 & 803 & 7,119 & ,000 \\
\hline & Labor & 3,749 & 2,438 & , 177 & 1,537 & , 137 \\
\hline & Equipment & 1,000 & 4,783 & 0.015 &,- 209 & ,836 \\
\hline
\end{tabular}

$\begin{array}{ll}\text { Source: Data processed }(2020) \\ \text { constant } & =22,032 \\ \text { R3 } & =0.925 \\ \text { F table } & =2.62 \\ \text { T table } & =1,711\end{array}$

In this section, the coefficient values of $\mathrm{a}, \mathrm{b} 1, \mathrm{~b} 2, \mathrm{~b} 3, \mathrm{~b} 4$, and $\mathrm{b} 5 \mathrm{t}$ are calculated and are significant. From the table can be obtained the equation:

$$
Y=34,080+0.017 X 1+0.033 X 2+0.631 X 3+3.749 X 4+1,000 \times 5
$$


Based on the table and equation above, it can be interpreted as follows:

1. F test

The R2 value of 0.925 indicates that $92.5 \%$ of lettuce production can be influenced by the variables of seeds, fertilizers, pesticides, labor and land area. Based on the $\mathrm{F}$ test that was carried out, it was obtained that Fcount $=61.228>$ Ftable 2.62 , meaning that seeds, fertilizers, pesticides, labor and equipment simultaneously significantly affected lettuce production in the study area because the results of multiple regression analysis (showing that (sig $=0.00>0.05$ )) which means that all the variables studied (seeds, fertilizers, pesticides, labor and equipment) have a significant effect on lettuce production in the study area.

\section{a. Seeds}

The value of 0.017 is the seedling coefficient (X1) which indicates that if the other independent variables have a fixed value and the seeds increase by 1 unit, the lettuce production will increase by $0.017 \mathrm{~kg}$. The sign of a positive coefficient for seeds means that the influence of seeds on lettuce production in the research area is positive, where the more lettuce seedlings tend to increase, the lettuce production in the research area will increase and vice versa. According to research by Tamalonggehe D. et al. (2014), which states that seeds have a positive effect on lettuce production.

\section{b. Fertilizer}

The value of 0.033 is the fertilizer coefficient (X2) which indicates that if the other independent variables have a fixed value and the fertilizer increases by 1 unit, it will increase lettuce production by $0.033 \mathrm{~kg}$. The sign of a positive coefficient for fertilizer means that the effect of fertilizer on lettuce production in the study area is positive, where the more fertilizer is added, the lettuce production in the study area will increase and vice versa. According to Suwalan et al. (2004) in Sahara and Idris (2010), the response of plants to fertilizer application will increase if the fertilizer used is the right type, dose, time and method of application.

\section{c. Pesticide}

The value of 0.0631 is the pesticide coefficient (X3) which indicates that if the other independent variables have a fixed value and the pesticide increases by 1 unit, the lettuce production will increase by $0.0631 \mathrm{~kg}$. The positive coefficient sign for pesticides means that the influence of pesticides on lettuce production in the research area is positive, where the increasing use of pesticides, the production of lettuce in the research area will increase and vice versa.

\section{d. Labor}

The value of 3.749 is the coefficient of labor (X4) which indicates that if the other independent variables are fixed in value and labor has increased by 1 unit. It will increase the production of lettuce by $3.749 \mathrm{~kg}$. The sign of a positive coefficient for labor means that the influence of labor on lettuce production in the research area is positive, where the increasing use of labor means lettuce production in the research area will increase and vice versa (Soekartawi, 1992).

e. Equipment

The value of 1,000 is the equipment coefficient (X5) which indicates that if the other independent variables have a fixed value and the equipment increases by 1 unit, it will increase lettuce production by $1,000 \mathrm{~kg}$. The positive coefficient sign for equipment means that the influence of equipment on lettuce production in the research area is positive, where the more equipment is added, the lettuce production in the research area will increase and vice versa. This study is in accordance with Tamalonggehe D. et al. (2014) research. Which states that the equipment has a positive effect on lettuce production.

\section{2. t-test}

\section{a. Seeds}

Partially, the seeds did not affect the production of lettuce. This can be seen from the value of tcount $<$ ttable $(0.047<1.711)$ then $\mathrm{HO}$ is accepted, meaning that there is no partial effect of the seed variable $(\mathrm{X} 1)$ on lettuce production $(\mathrm{Y})$, then this means that the seed does not have a significant effect on lettuce.

b. Fertilizer

Partially, fertilizers do not affect lettuce production. This can be seen from the value of tcount $<$ ttable $(0.742<1.711)$ then $\mathrm{HO}$ is accepted, meaning that there is no partial effect of fertilizer variable (X2) on lettuce production (Y), then this means that fertilizer does not have a significant effect on lettuce production, because more and more fertilizers are used, it will reduce lettuce production and increase production costs. 
c. Pesticide

Partially, pesticides have an effect on lettuce production. It can be seen from the value of tcount $<$ ttable $(7.119<1.711)$ then $\mathrm{H} 1$ is accepted, meaning that partially there is an effect of pesticide variable (X3) on lettuce production (Y).

d. Labor

In terms of labor, it has no effect on lettuce production. It can be seen from the value of tcount $<$ ttable $(1.533<1.711)$ then $\mathrm{H} 0$ is accepted, meaning that it does not partially affect the labor variable (X4) on lettuce production (Y) because the t-count value is less than the t-table value and the significant value of $t$ is greater than the level of significance (0.05), then this means that labor does not have a significant effect on lettuce production.

e. Equipment

Partially equipment, affect the production of lettuce. It can be seen from the value of tcount $<$ ttable $(5.965<1.711)$ then $\mathrm{H} 1$ is accepted, meaning that it partially affects the equipment variable (X5) on lettuce production (Y), because the t-count value is more than the t-table value, then this means that the equipment has an influence on lettuce production in the study area.

\section{Conclusion}

The use of production inputs (seeds, fertilizers, pesticides, labor, and equipment) significantly affects lettuce production in the study area. The level of efficiency in the use of production factors (seeds, fertilizers, pesticides, labor, and equipment) has not been technically, price, and economically efficient. Lettuce farming income in the research area is low. In an effort to increase the efficiency of lettuce farming, farmers are increasing the use of production factors such as the use of seeds and fertilizers according to the recommended amount and time of application. The government is advised to continue to pay attention to the need for production facilities such as fertilizers and pesticides by controlling the distribution of fertilizers and pesticides. Researchers are expected to be able to conduct further research on technical efficiency.

\section{References}

[1] Agustina S, M. (2001). Farming Science, Malang. Brawijaya University

[2] Central Bureau of Statistics, (2018). Gross Domestic Product, Indonesia. 2014-2018 years. Jakarta: Central Bureau of Statistics.

[3] Dahlan, S. M. (2013). Sample Size and Sampling Method. Jakarta: Salemba Medika

[4] Department of Agriculture, Food Crops and Horticulture. (2018). Harvest Area and Vegetable Production in North Sumatra Province. Department of Agriculture, Food Crops and Horticulture, North Sumatra Province.

[5] Edi, S., and J. Bobihoe. (2010). Cultivation of Vegetable Crops. Center for the Study of Agricultural Technology. Jambi.

[6] Firdaus, M. (2011). Agribusiness Management. Jakarta: Earth Literacy

[7] Juniarsih, T. (2012). Effect of Gross Regional Domestic Product (GDP) of the Agricultural Sector on GRDP. Thesis.

[8] Kuncoro, M. (2010). Fundamentals of Development Economics, UPP STIM YKPN Yogyakarta.

[9] Lawalata, M., Darwanto H.D and Hartono, S (2015). The Relative Efficiency of Shallot Farming in Bantul Regency Using a Data Envelopment Analysis (DEA) Approach. Journal of Agricultural Sciences.

[10] Lingga, L. (2010). Smart Choosing Vegetables. Jakarta: Agro Media Pustaka Publisher.

[11] Mas'ud, H. (2009). Hydroponic Systems with Different Nutrients and Growing Media on Growth and Yield of Lettuce. Central Sulawesi Research and Development Media.

[12] Mudrajad, K. (2010). Fundamentals of Development Economics, UPP STIM YKPN Yogyakarta.

[13] Mubyarto (2008). Introduction to Agricultural Economics, Jakarta: Third Edition, LP3S.

[14] Nachrowi, D. N and Hardius U. (2006). Popular Practical Econometrics Approaches for Economic and Financial Analysis. Jakarta.

[15] Nicholson, W. (2015). Microeconomic Theory Basic Principles and Its Development. Jakarta: PT. King Grafindo Persada.

[16] Novriani, (2014). Response of Lettuce (Lactuca Sativa L) to Application of Liquid Organic Fertilizer from Waste. 